Original Article

\title{
Comparative brain analysis of wild and hatchery reared Mahseer (Tor putitora) relative to their body weight and length
}

\author{
Análise comparativa do cérebro de Mahseer (Tor putitora) selvagem e criado em \\ incubatório em relação ao peso e comprimento corporal
}

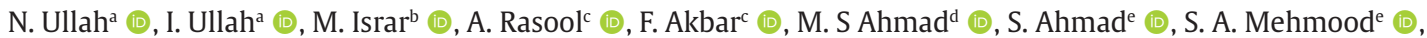

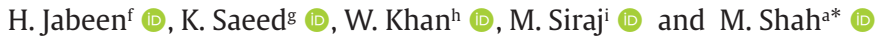 \\ aCentre for Animal Sciences and Fisheries, University of Swat, Swat, Pakistan \\ bDepartment of Forensics Sciences, University of Swat, Swat, Pakistan \\ 'Centre for Biotechnology and Microbiology, University of Swat, Swat, Pakistan \\ dDepartment of Zoology, University of Swabi, Swabi, Pakistan \\ eDepartment of Zoology, Hazara University Mansehra, Mansehra, Pakistan \\ fDepartment of Microbiology, Women University Mardan, Mardan, Pakistan \\ ${ }^{g}$ Department of Zoology, University of Buner, Buner, Pakistan \\ hDepartment of Zoology, University of Malakand, Chakdara, Pakistan \\ 'Department of Zoology, Abbottabad University of Science \& Technology, Abbottabad, Pakistan
}

\begin{abstract}
The present study was aimed at comparing the brain size of mahseer (Tor putitora) in relation to their body weight and standard length, to investigate the potential impact of rearing environment on brain development in fish. The weight of the brain and three of its subdivisions cerebellum (CB), optic tectum (OT), and telencephalon (TC) were measured for both wild and hatchery-reared fish. The data was analysed using multiple analysis of covariance (MANCOVA), analysis of covariance (ANCOVA), and discriminate function analysis (DFA). We found the fish reared under hatchery conditions exhibit smaller brain size related to body weight, when compared to the wild ones. A significant $(p<0.5)$ difference was observed in the length of CB and OT concerning the standard body length while no significant difference was found in TC of the fish from both the origins. The results of the current study highlight a logical assumption that neural deficiency affects the behaviour of fish, that's why the captive-reared fish show maladaptive response and face fitness decline when released to the natural environment for wild stock enhancement. The current study concluded that hatchery-reared fish exhibit variations in gross brain morphology as compared to their wild counterpart.
\end{abstract}

Keywords: morphometry, fish research station Thana, Malakand agency, Swat.

\section{Resumo}

O presente estudo teve como objetivo comparar o tamanho do cérebro de mahseer (Tor putitora) em relação ao seu peso corporal e comprimento padrão, para investigar o impacto potencial do ambiente de criação no desenvolvimento do cérebro em peixes. $O$ peso do cérebro e três de suas subdivisões - cerebelo (CB), tectum óptico (OT) e telencéfalo (TC) - foram medidos para peixes selvagens e criados em incubadoras. Os dados foram analisados usando análise múltipla de covariância (MANCOVA), análise de covariância (ANCOVA) e análise de função discriminante (DFA). Descobrimos que os peixes criados em condições de incubação apresentam menor tamanho do cérebro em relação ao peso corporal quando comparados aos selvagens. Uma diferença significativa $(\mathrm{p}<0,5)$ foi observada no comprimento do CB e OT em relação ao comprimento corporal padrão, enquanto nenhuma diferença significativa foi encontrada no CT dos peixes de ambas as origens. Os resultados do estudo atual destacam uma suposição lógica de que a deficiência neural afeta o comportamento dos peixes. É por isso que os peixes criados em cativeiro mostram uma resposta mal adaptativa e enfrentam declínio de aptidão quando liberados no ambiente natural para o aprimoramento do estoque selvagem. $\mathrm{O}$ estudo atual concluiu que os peixes criados em incubadoras exibem variações na morfologia cerebral bruta em comparação com suas contrapartes selvagens.

Palavras-chave: morfometria, estação de pesquisa de peixes de Thana, agência Malakand, Swat.

*e-mail: muzafar@uswat.edu.pk

Received: November 27, 2019 - Accepted: September 14, 2020 


\section{Introduction}

Animals are frequently captive reared for the production of quality meat, pet trade, potential use in laboratory experiments, recreation and conservation (Salvanes and Braithwaite, 2006; Naslund et al., 2012). Fish are widely used for all the aforementioned purposes (Burns et al., 2009). Millions of dollars have been invested throughout the world in the artificial rearing of fish for these purposes. However, the use of hatcheries rearing to produce fish similar to their wild counterparts are often strongly criticized by evolutionary ecologists and biologists (Marchetti and Nevitt, 2003; Aprahamian et al., 2003; Fraser, 2008; McClure et al., 2008) because hatchery-raised fish are known to differ phenotypically (Brown and Laland, 2001; Marchetti and Nevitt, 2003) and consequently less efficient in preventing wild population declines due to inferior rate of their survival in a natural environment just like the wild raised same fish species (Saloniemi et al., 2004; Huntingford et al., 2006; Araki et al., 2008).

Captive-reared fishes usually grew under barren environments within a limited landscape. Such a rearing environment have harmful impact on neural and behavioral development. The study of Van-Praag et al. (2000) and Rosenzweig and Bennett, (1996) on captive reared rodetns, cats, sheep and pigs revealed that these mammals have smaller brain size (ranging from 8-33\%) as compared to their wild progenitors with respect to their body size (Burns et al., 2009). Initially, it was thought that unintentional selection pressure in the control environment was the main attributor to such deviation. Braithwaite and Salvanes, 2005) but later on the influence of control rearing was observed to be directly altering the phenotype of fish in captivity (Kihslinger and Nevitt, 2006: Burns et al., 2009; Mayer et al., 2011). Hatchery-reared fish display marked morphological (Vehanen and Huusko, 2011; Fleming et al., 1996), anatomical (Vehanen and Huusko, 2011), physiological (Johnsson et al., 2001) and behavioral (Naslund et al., 2012) differences when compared to their wild counterparts. This can be interpreted as a maladaptive behavioral response in wild, and cause fitness decline (Brown and Laland, 2001; Biro et al., 2004; Larsson et al., 2011). Research face greater problem regarding the issues of using farmed fish in basic research programs to know about their behavior and to interpolate these results to the behavior of their wild counterparts is well documented (Naslund et al., 2012).

Recent studies on the brain development of farmed fish revealed a reduced overall brain size (Marchetti and Nevitt, 2003; Kihslinger et al. 2006; Mayer et al., 2011). The gross brain morphology in animals is thought to be affecting their cognitive (spatial learning and problem solving) abilities, however, this assumption still needs to be validated and elaborated in more detail (Healy and Rowe, 2007; Lefebvre and Sol, 2008). The brain substructures are multifunctional to a certain degree, but their relative size generally corresponds to the ecological niche of the animal, specifically more evident in fish (Kotrschal et al., 1998). Therefore, the size of regions of the brain would likely reflect the relative importance of the senses or behavioral traits that it controls (Shumway, 2008).
Various researchers have comprehensively investigated the correlation between the brain size and behavioral traits in birds and mammals (Rehkamper et al., 2003) have provided a predictive neuro-ecological hypothesis on the whole brain size of these taxa (Kolm et al., 2009). Fish has been less studied, yet some studies revealed a continuous growth in the fish brain throughout their life, which is not possible in other taxa (Zupanc, 2006). The environmental conditions are known to have a greater role in the structural and functional development of the brain in all investigated organisms. Behavioral responses such as territoriality, communication, courtship, parental care etc. are correlated with brain size, larger the brain size in animal will lead to well-developed behavioral responses (Hubert et al., 1997; Kotrschal et al., 1998; Salvanes and Braithwaite., 2006; Kihslinger et al., 2006). Responses to social and environmental stimuli such as light, sound, temperature, touch, pressure, social calls are controlled by the brain (Pollen et al., 2007; Gonda et al., 2009; Naslund et al., 2012). Environmental deprivation during the juvenile stage of the life could lead to smaller brain size, and potentially limit behavioral skills (Kihslinger et al., 2006). In the present study, we adopted a simple morphological approach to investigate the impact of rearing conditions on the brain development of Mahseer, Tor putitora. We hypothesized that captive condition changes fish brain development. The hypothesis was tested by comparing the gross brain morphology of wild and hatchery-reared fish specimens. We aimed to explore the impact of two considerably different rearing environments on brain development in fish and causes of these neural deviations.

\section{Materials and Methods}

The current study was conducted from June 2016 to September 2016. The collection was carried out from the wild and hatchery. The samples were transported to the laboratory for further analysis.

\subsection{Sampling}

A total of 26 specimens (fingerlings and adult) were selected from two considerably different rearing environments for the experiments. The age of hatchery reared fish was upto 6 months. Of these, eighteen (18) specimens were collected from wild habitat (River Swat) while the remaining eight (08) specimens from Mahseer Fish Research Station Thana, District Malakand. The collected samples were preserved in $10 \%$ formalin. Then the samples were transferred to the Laboratory (Centre for Animal Sciences and Fisheries, the University of Swat) for further analysis.

Identification and Morphometry: Wild samples were identified by following different taxonomic and systematic keys (Mirza, 2007). The morphometric measurement of the body (standard length) was found out for each sample with the least error of \pm 0.5 and weighed ( $\pm 0.01 \mathrm{~g}$ ). 


\subsection{Study of Brain}

Heads were detached from the body and held in an upright position for brain extraction. The entire soft tissues of the surrounding skull were removed. The skull was then carefully cut with the help of a sharp cutter. The skull bone was carefully removed with the help of forceps to avoid damage to the dorsal part of the brain. The dorsal part of the cranium was removed and the brain was exposed for a further incision. The lateral part of the cranium was removed with the help of small dissecting scissors. The optic nerves and other nerves from the brain and brain stem were carefully detached with the help of scissor to avoid damage to the brain. The brain from the bottom was gently lifted out. Few samples were missed out (04) during the extraction of the brain from the lateral part of the cranium. The photographs were captured through Canon lens 20x, 4.5-90.0mm. The brain was weighed ( $\pm 0.51 \mathrm{~g}$ ) with the help of digital weight balance.

The brain substructure were detached from each other by using scissors. The total brain length and dorsally notable substructures of the brain, cerebellum (CE), optic tectum (OT), and telencephalon (TC) (Figure 1) were measured by digital Vernier Calliper (Mitutoyo-Japan). In the case of the missing pair, the other half part was calculated twice. The brain samples were freeze for preservation.

\section{Data Analysis}

Multiple analyses of covariance (MANCOVA) model was employed to investigate the difference in brain size of wild and hatchery-reared fish in relation to their standard body length and weight. For each brain measures, analysis of covariance (ANCOVA) model was employed. A $p$-value $(<0.05)$ was considered significant statistically. Data for the ANCOVA and MANCOVA models were in $(x+1)$ transformed before statistical analysis.

Discriminant function analysis (DFA) was used to distinguish the three substructure of the brain of the

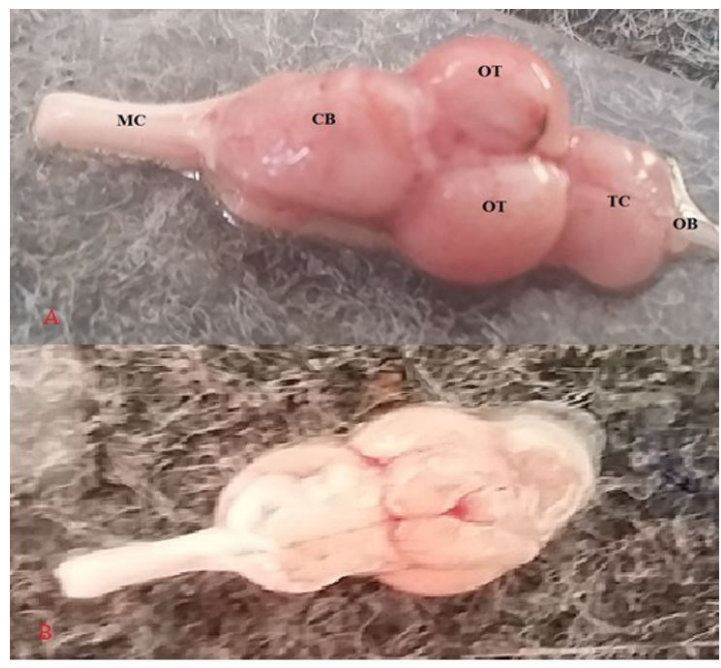

Figure 1. A: Dorsal \& B: ventral view of the fish brain. fish, from both wild and hatchery. The sub-structure of the brain with standard length and body weight of the fish was standardized to control the overall brain size differences. All the statistical analyses were carried out by using JMP (Marchetti and Nevitt, 2003).

\section{Results}

The total length of wild and hatchery samples were $27.50 \pm 0.59$ and $8.75 \pm 0.20$; fork length $24.74 \pm 0.63$ and $7.78 \pm 0.18$; and the standard length were $21.70 \pm 0.55$ and $6.51 \pm 0.24$ respectively (Table 1 ). The standard length of both the fish were selected for comparative analysis with brain measure. The body (gm) and brain weight (mg) of the wild and hatchery-reared fish were also analyzed. The mean body weight of wild fish was $254.16 \pm 18.43$ while hatchery fish was $6.25 \pm 0.53$. Similarly, the mean brain weight $(\mathrm{mg}$ ) of the wild fish was $400.33 \pm 17.62$ and hatchery-reared fish was $99.75 \pm 9.60$ respectively (Table 2 ). A significant difference in brain weight concerning the total body weight of both fish was observed. The relationship of the body and brain weight of both fish showed that the wild fish has a heavier brain

Table 1. Mean morphometry of wild and hatchery reared Mahseer $(\mathrm{cm})$

\begin{tabular}{crrr}
\hline Fish origin & \multicolumn{1}{c}{ TL } & \multicolumn{1}{c}{ FL } & \multicolumn{1}{c}{ SL } \\
\hline Wild & $27.50 \pm 0.59$ & $24.74 \pm 0.63$ & $21.70 \pm 0.55$ \\
Hatchery & $8.75 \pm 0.20$ & $7.78 \pm 0.18$ & $6.51 \pm 0.24$ \\
\hline
\end{tabular}

TL: total length, FL: fork length and SL: standard length, $\mathrm{cm}$ : centimeter.

Table 2. Means of the body (gm) and brain weight (mg)

\begin{tabular}{ccc}
\hline Fish origin & Body weight & Brain weight \\
\hline Wild & $254.16 \pm 18.43$ & $400.33 \pm 17.62$ \\
Hatchery & $6.25 \pm 0.53$ & $99.75 \pm 9.60$ \\
\hline
\end{tabular}

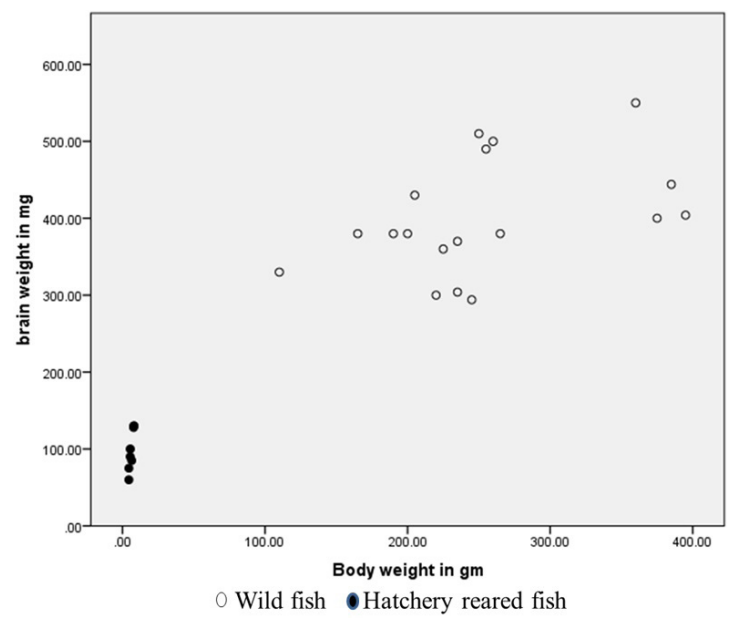

Figure 2. Relationship between body and brain weight of wild and hatchery reared fish. 
in relation to their total body weight as compared to the hatchery-reared fish (Figure 2).

The mean total brain length of both wild and hatchery fish was $18.22 \pm 0.77$ and $9.50 \pm 0.24$ respectively. The mean length of $\mathrm{CB}$ was $7.36 \pm 0.21$ and $3.8 \pm 0.12$; OT was $6.89 \pm 0.15-3.52 \pm 0.09)$ and TC was $4.88 \pm 0.19$ $2.68 \pm 0.06$ (Table 3).

A significant ( $p>0.5)$ difference in CB and OT in both wild and hatchery-reared fish in respect of their standard length was observed (Table 4). The size of CB and OT of Hatchery fish was smaller than wild fish (Figure 3 \& 4 ). However, there was no significant difference in the length of Telencephalon (TC) of wild and hatchery-reared fish (Table 4).

\section{Discussion}

The current study demonstrated the variation in the morphology of the brain of mahseer (Tor putitora) fish under captive and wild conditions. It was observed that mahseer rose under hatchery condition exhibit a considerable reduction in gross neural anatomy (CB and OT measure of the brain) as compared to their wild counterparts observed via simple anatomical measurements of the brain. It might be attributed to the changed rearing environment that the hatchery-reared fish were having smaller measurements as compared to the wild ones, however, the main factors behind it are still to be explored.

Table 3. Means length of the brain and different parts of the brain sub-structure ( $\mathrm{mm}$ ).

\begin{tabular}{ccccc}
\hline Fish origin & Cerebellum & Optic tectum & Telencephalon & Total brain \\
\hline Wild & $7.36 \pm 0.21$ & $6.89 \pm 0.15$ & $4.88 \pm 0.19$ & $18.22 \pm 0.77$ \\
Hatchery & $3.8 \pm 0.12$ & $3.52 \pm 0.09$ & $2.68 \pm 0.06$ & $9.50 \pm 0.12$ \\
\hline
\end{tabular}

Table 4. MANCOVA and ANOVA result. All brain measures are in $(x+1)$ transformed. Three of five Dependent Variables showed a significant difference $(p<0.5)$, such as brain weight CB and OT length. TL represents the total length.

\begin{tabular}{rlcccccccc}
\hline Source & $\begin{array}{c}\text { Dependent } \\
\text { Variable }\end{array}$ & $\begin{array}{c}\text { Type III Sum } \\
\text { of Squares }\end{array}$ & Df & $\begin{array}{c}\text { Mean } \\
\text { Square }\end{array}$ & F & Sig. & $\begin{array}{c}\text { Partial Eta } \\
\text { Squared }\end{array}$ & $\begin{array}{c}\text { Nocent. } \\
\text { Parameter }\end{array}$ & $\begin{array}{c}\text { Observed } \\
\text { Power }\end{array}$ \\
\hline $\begin{array}{l}\text { Brain weight } \\
\text { in mg }\end{array}$ & 59757.315 & 1 & 59757.315 & 18.027 & .000 & .450 & 18.027 & .982 \\
$\begin{array}{l}\text { CB length in } \\
\text { mm }\end{array}$ & 3.348 & 1 & 3.348 & 7.113 & .014 & .244 & 7.113 & .722 \\
Origin & $\begin{array}{l}\text { OT length in } \\
\text { mm }\end{array}$ & 7.604 & 1 & 7.604 & 22.236 & .000 & .503 & 22.236 & .994 \\
& $\begin{array}{l}\text { TL length in } \\
\text { mm }\end{array}$ & .096 & 1 & .096 & .310 & .583 & .014 & .310 & .083 \\
& $\begin{array}{l}\text { TL Brain } \\
\text { length mm }\end{array}$ & 3.047 & 1 & 3.047 & .633 & .435 & .028 & .633 & .119 \\
\hline
\end{tabular}

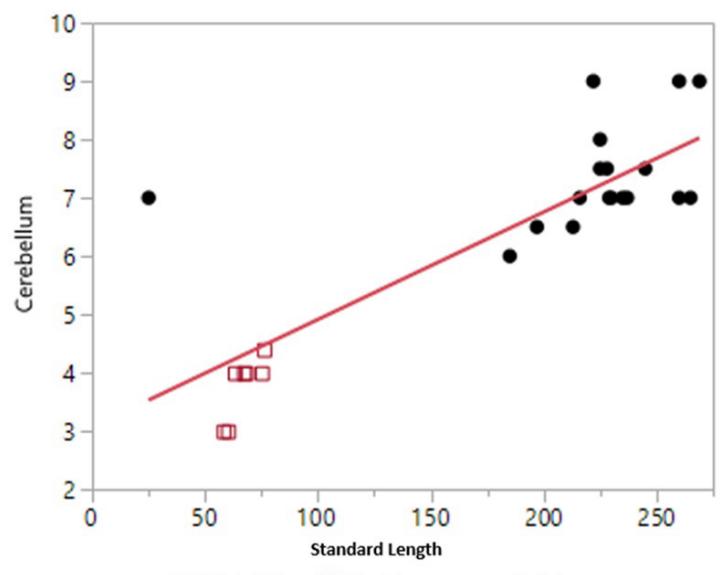

- Wild fish $\square$ Hatchery reared fish

Figure 3. Relationship between standard length and cerebellum of wild and hatchery reared fish.

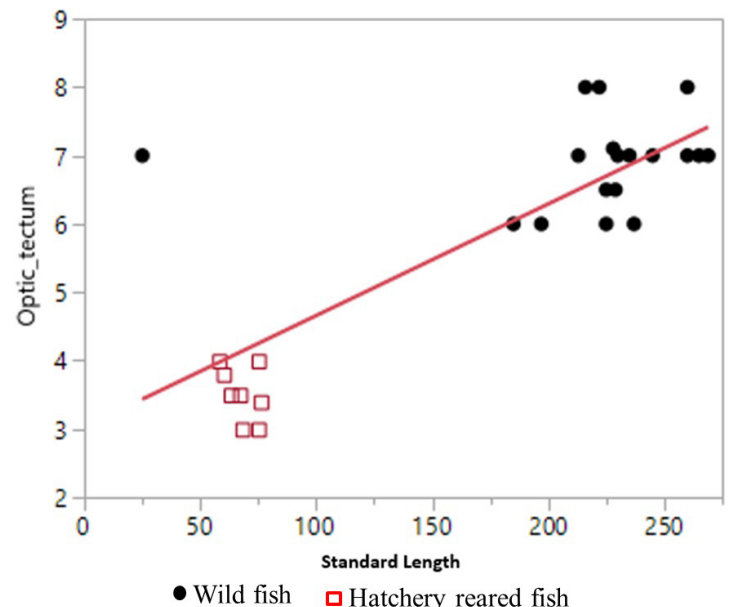

Figure 4. Relationship between standard length and optic tectum of wild and hatchery reared fish. 
It has been reported by various researchers that salmonids fishes under domestication developed a noticeable change in their brain morphology (Marchetti and Nevitt, 2003; Lema and Nevitt, 2004; Kihslinger et al., 2006; Naslund et al., 2012). Our result showed the closest consistency with the observation on Rainbow trout (Oncorhynchus mykiss) (Marchetti and Nevitt, 2003). They analysed eight different brain measure of the fish for both the origin relating to their standard body length and found notable differences in them. They found that hatchery-reared fish display small brain size, more specifically in the telencephalon and optic tectum as compared to their wild specimens, which is congruent to the current study. In the current study, the hatchery-reared stock of mahseer also exhibited smaller brain size by weight in regard their body weight and standard length as compare to the wild ones. However, no significant difference in the size of telencephalon was observed in the current study. Our study is consistent with the findings of Mayer et al. (2011) on wild and domesticated Atlantic cod (Gadus morhua). They also reported that the reared Atlantic cod exhibited smaller brain size by weight than wild cod in relation to total body weight.

It has been testified by various researchers that ecological condition such as habitat enrichment is predominantly correlated with shaping brain size. It is known that environmental conditions vary between wild and hatchery, and hence are experienced differently by fish at both the origins. Kihslinger et al. (2006) reported that salmon (Oncorhynchus mykiss) raised under an enriched rearing pond exhibited the same neural phenotype as compared to their wild counterparts while those reared under normal hatchery environment displayed smaller brain size than the wild ones. Pollen et al. (2007) also found that the development of forebrain structures such as the cerebellum and telencephalon of cichlid fishes shows a positive growth rate to an environmental condition. Cichlid fishes found in enriched environmental conditions exhibited a greater size of the brain as compared to the unreached rearing environment, but we found no differences in the size of telencephalon between wild and hatchery-reared fish. The effects of environmental conditions on brain development has been well documented in other taxa including rodents, rabbits, cats, sheep, and pigs, revealing that captive-reared animals had smaller brain size (18-33\%) associated to their body size as compared to the wild ones (reviewed in Rosenzweig and Bennett, 1996; Van Praag et al., 2000; Burns et al., 2009).

Recent studies have shown that brain development correlates with environmental complexity and social factors. As compared to social interaction, environmental factors are known to have a greater role in the brain differentiation of fish (Pollen et al., 2007). Naslund et al. (2012) found that farmed salmon (Salmo salar) under enriched environmental condition display larger brain size than salmon reared under normal hatchery conditions. The same results have been reported by Kihslinger et al. (2006), as they found that the manipulation of a few small stones to rearing environment altered the growth of the cerebellum size in reared rainbow trout (Oncorhynchus mykiss). The fish brain grows continuously throughout life, suggesting the elastic and receptive response of their brain to environmental conditions (Kihslinger and Nevitt, 2006). Such plasticity of the brain to the environment has been recently testified by raising fish in the laboratory. Burns et al. (2009) revealed that guppies (Poecilia reticulata) reared under laboratory conditions had smaller brain size, specifically the optic tectum and telencephalon as compared to wild guppies.

Besides environmental complexity, it has been found that the social environment also caused well pronounced changes in the development of the brain in fish. Gonda et al. (2009) demonstrated that pond raised nine-spined sticklebacks (Pungitius pungitius) displayed smaller brain size under crowded conditions as compared to the fish raised individually. The effect of social environments on brain growth in cichlid fish is studied by Pollen et al. (2007), and they suggested that amongst closely related cichlid fish species shallow water feeding species displayed different neural architecture than deep-water feeding species. These observations revealed the social environment encountered under intensive aquaculture conditions, such as high densities, may have an influence on brain plasticity in farmed fish, which might be similar for mahseer as well.

The current study revealed the impact of culture condition on brain architecture and behavioral development. A notable difference was found in whole brain weight corresponding body weight and length between wild and hatchery-reared mahseer. Tor putitora reared under hatchery condition displayed no significant differences in telencephalon as compare to their wild counterparts. However, further studies are suggested to know more about the factors contributing to the difference in brain morphology/anatomy and to answer how hatchery-reared individuals exhibit smaller brain as compared to their wild counterparts, and whether such differences in neural phenotype can be compensated by providing enrichment habitat as observed for salmonids fishes.

An advanced type of culture system should be established to ensure the development of wild characters/ traits/behavior and neural development, so as they can survive and thrive in nature, and can contribute to the purpose of economy generation, conservation, and ecology enrichment. The release of unfit fish to the wild should be avoided and IUCN guidelines for stocking/restocking should be followed to avoid resources wastage.

\section{References}

APRAHAMIAN, M.W., MARTIN SMITH, K., MCGINNITY, P., MCKELVEY, S. and TAYLOR, J., 2003. Restocking of salmonids opportunities and limitations. Fisheries Management and Ecology, vol. 62, no. 2, pp. 211-227. http://dx.doi.org/10.1016/S0165-7836(02)00163-7.

ARAKI, H., BEREJIKIAN, B.A., FORD, M.J. and BLOUIN, M.S., 2008. Fitness of hatchery-reared salmonids in the wild. Evolutionary Applications, Vol. 1. pp. 342-355.

BIRO, P.A., ABRAHAMS, M.V., POST, J.R. and PARKINSON, E.A., 2004. Predators select against high growth rates and risk-taking behavior in domestic trout populations. Proceedings. Biological Sciences, vol. 271, pp. 2233-2237.

BRAITHWAITE, V.A. and SALVANES, G.A., 2005. Environmental variability in the early rearing environment generates behaviourally flexible cod: implications for rehabilitating wild populations. Procedings of the Royal Society, Vol. 10, pp. 1098-3062. 
BROWN, C. and LALAND, K., 2001. Social learning and life skills training for hatchery reared fish. Journal of Fish Biology, vol. 59, no. 3, pp. 471-493. http://dx.doi.org/10.1111/j.1095-8649.2001.tb02354.x.

BURNS, J.G., SARAVANAN, A. and HELEN RODD, F., 2009. Rearing environment affects the brain size of guppies: lab-reared guppies have smaller brains than wild-caught guppies. Ethology, vol. 115, no. 2, pp. 122-133. http://dx.doi.org/10.1111/j.1439-0310.2008.01585.x.

FLEMING, I.A., JONSSON, B., GROSS, M.R. and LAMBERG, A., 1996. An experimental study of the reproductive behavior and success of farmed and wild Atlantic salmon (Salmo salar). Journal of Applied Ecology, vol. 33, no. 4, pp. 893-905. http:// dx.doi.org/10.2307/2404960.

FRASER, D.J., 2008. How well can captive breeding programs conserve biodiversity? A review of salmonids. Evolutionary Applications, vol. 1, no. 4, pp. 535-586. http://dx.doi.org/10.1111/ j.1752-4571.2008.00036.x. PMid:25567798.

GONDA, A., HERCZEG, G. and MERILA, J., 2009. Habitat-dependent and - independent plastic responses to social environment in the nine-spined stickleback (Pungitius pungitius) brain. Proceedings. Biological Sciences, vol. 276, no. 1664, pp. 2085-2092. http:// dx.doi.org/10.1098/rspb.2009.0026. PMid:19324759.

HEALY, S.D. and ROWE, C., 2007. A critique of comparative studies of brain size. Proceedings. Biological Sciences, vol. 274, no. 1609, pp.453464. http://dx.doi.org/10.1098/rspb.2006.3748. PMid:17476764.

HUBERT, R., VAN STAADEN, M.J., KAUFMAN, L.S. and LIEM, K.F., 1997. Microhabitat use, trophic patterns, and the evolution of brain structure in African cichlids. Brain, Behavior and Evolution, vol. 50, no. 3, pp. 167-182. http://dx.doi.org/10.1159/000113330. PMid:9288416.

HUNTINGFORD, F.A., ADAMS, C., BRAITHWAITE, V.A., KADRI, S. POTTINGER, T.G., SANDOE, P. and TURNBULL, J.F., 2006. Current issues in fish welfare. Journal of Fish Biology, vol. 68, no. 2, pp. 332-372. http://dx.doi.org/10.1111/j.0022-1112.2006.001046.x.

JOHNSSON, J.I., HOJESJO, J. and FLEMING, I.A., 2001. Behavioural and heart rate responses to predation risk in wild and domesticated Atlantic salmon. Canadian Journal of Fisheries and Aquatic Sciences, vol. 58, no. 4, pp. 788-794. http://dx.doi.org/10.1139/f01-025.

KIHSLINGER, R.L. and NEVITT, G.A., 2006. Early rearing environment impacts cerebella growth in juvenile salmon. The Journal of Experimental Biology, vol. 209, no. Pt 3, pp. 504-509. http:// dx.doi.org/10.1242/jeb.02019. PMid:16424100.

KIHSLINGER, R.L., LEMA, S.C. and NEVITT, G.A., 2006. Environmental rearing conditions produce forebrain differences in wild Chinook salmon (Oncorhynchus tshawytscha). Comparative Biochemistry and Physiology. Part A, Molecular E Integrative Physiology, vol. 145, no.2, pp. 152-151.http://dx.doi.org/10.1016/j.cbpa.2006.06.041.PMid:16890467.

KOLM, N., GONZALEZ-VOYER, A., BRELIN, D. and WINBERG, S., 2009. Evidence for small scale variation in the vertebrate brain: mating strategy and sex affect brain size and structure in wild brown trout (Salmo trutta). Journal of Evolutionary Biology, vol. 22, no. 12, pp. 2524-2531. http://dx.doi.org/10.1111/j.14209101.2009.01875.x. PMid:19878498.

KOTRSCHAL, K., VAN STAADEN, M.J. and HUBER, R., 1998. Fish brains: evolution and environmental relationships. Reviews in Fish Biology and Fisheries, vol. 8, no. 4, pp. 73-408. http:// dx.doi.org/10.1023/A:1008839605380.

LARSSON, S., LINNANSAARI, T., VATANEN, S., SERRANO, I. and HAIKONEN, A., 2011. Feeding of wild and hatchery reared Atlantic salmon (Salmo salar) smolts during downstream migration. Environmental Biology of Fishes, vol. 92, no. 3, pp. 361-369. http://dx.doi.org/10.1007/s10641-011-9846-7.

LEFEBVRE, L. and SOL, D., 2008. Brains lifestyles and cognition: are there general trends. Brain Behavior and Evolution, vol. 72, no. 2, pp. 135-144. http://dx.doi.org/10.1159/000151473. PMid:18836259.
LEMA, S.C. and NEVITT, G.A., 2004. Evidence that thyroid hormone induces olfactory cellular proliferation in salmon during a sensitive period for imprinting. The Journal of Experimental Biology, vol. 207, no. Pt 19, pp. 3317-3327. http://dx.doi. org/10.1242/jeb.01143. PMid:15326208.

MARCHETTI, M.P. and NEVITT, G.A., 2003. Effects of hatchery rearing practices on brain structures of rainbow trout (Oncorhynchus mykiss). Environmental Biology of Fishes, vol. 66, no. 1, pp. 9-14. http://dx.doi.org/10.1023/A:1023269221678.

MAYER, I., MEAGER, J., SKJARASEN, J., RODEWALD, P., SVERDRUP, G. and FERNO, A., 2011. Domestication causes rapid changes in heart and brain morphology in Atlantic cod (Gadus morhua). Environmental Biology of Fishes, vol. 92, pp. 181-186.

MCCLURE, M.M., UTTER, F.M., BALDWIN, C., CARMICHAEL, R.W., HASSEMER, P.F., HOWELL, P.J., SPRUELL, P., COONEY, T.D., SCHALLER, H.A., and PETROSKY, C.E., 2008. Evolutionary effects of alternative artificial propagation programs: implications for viability of endangered anadromous salmonids. Evolutionary Applications. Vol. 1, pp. 356-375.

MIRZA, M.R. 2007. Fishes of Punjab, Pakistan. Lahore, Pakistan: Polymer Publication.

NASLUND, J., AARESTRUP, K. and SOREN, T., 2012. Early enrichment effects on brain development in hatchery-reared Atlantic salmon (Salmo salar): no evidence for a critical period. Canadian Journal of Fisheries and Aquatic Sciences, vol. 69, no. 9, pp. 1481-1490. http://dx.doi.org/10.1139/f2012-074.

POLLEN, A.A., DOBBERFUHL, A.P., SCACE, J., IGULU, M.M., RENN, S.C.P., SHUMWAY, C.A. and HOFMANN, H.A., 2007. Environmental complexity and social organization sculpt the brain in Lake Tanganyikan cichlid fish. Brain, Behavior and Evolution. Vol. 70, pp. 21-39.

REHKAMPER, G., KART, E., FRAHM, H.D. and WERNER, C.W., 2003. Discontinuous variability of brain composition among domestic chicken breeds. Brain, Behavior and Evolution, vol. 61, no. 2, pp. 59-69. http://dx.doi.org/10.1159/000069352. PMid:12660443.

ROSENZWEIG, M.R. and BENNETT, E.L., 1996. Psychobiology of plasticity: effects of training and experience on brain and behaviour. Behavioural Brain Research, vol. 78, no. 1, pp. 57-65. http://dx.doi.org/10.1016/0166-4328(95)00216-2. PMid:8793038.

SALONIEMI, I., JOKIKOKKO, E., KALLIO-NYBERG, I., JUTILA, E. and PASANEN, P., 2004. Survival of reared and wild Atlantic salmon smolts: size matters more in bad years. ICES Journal of Marine Science, vol. 61, no. 5, pp. 782-787. http://dx.doi.org/10.1016/j. icesjms.2004.03.032.

SALVANES, G.A. and BRAITHWAITE, V., 2006. The need to understand the behavior of fish reared for Mari culture or restocking. ICES Journal of Marine Science, vol. 63, pp. 346-354.

SHUMWAY, C.A., 2008. Habitat complexity, brain and behavior. Brain, Behavior and Evolution, vol. 72, no. 2, pp. 123-134. http:// dx.doi.org/10.1159/000151472. PMid:18836258.

VAN PRAAG, H., KEMPERMANN, G. and GAGE, F.H., 2000. Neural consequences of environmental enrichment. Nature Reviews Neuroscience, vol. 1, no. 3, pp. 191-198. http://dx.doi. org/10.1038/35044558. PMid:11257907.

VEHANEN, T. and HUUSKO, A., 2011. Brown trout Salmo trutta express different morphometrics due to divergence in the rearing environment. Journal of Fish Biology, vol. 79, no. 5, pp. 1167-1181. http://dx.doi.org/10.1111/j.1095-8649.2011.03093.x. PMid:22026600.

ZUPANC, G., 2006. Neurogenesis and neuronal regeneration in the adult fish brain. Journal of Comparative Physiology. A, Neuroethology, Sensory, Neural, and Behavioral Physiology, vol. 192, no. 6, pp. 649-670. http://dx.doi.org/10.1007/s00359-0060104-y. PMid:16463148. 